Instructions for authors, subscriptions and further details:

\title{
http://rimcis.hipatiapress.com
}

\section{Digital Literacy and Online Child Abuse among Primary School Children in Langata Sub-county, Nairobi City County in Kenya}

Wilkins Ndege Muhingi ${ }^{1}$, Johnson Nzau Mavole ${ }^{2}$, Mumo Nzau ${ }^{3}$

1) Pan Africa Christian University, Kenya

2) St. Augustine University of Tanzania, Tanzania

3) University of Nairobi, Kenya

Date of publication: Online First 05 April 2021, Issue published 30 July 2021 Edition period: March 2021 - July 2021

To cite this article: Muhingi, W.N., Mavole, J.N., \& Nzau, M. (2021). Digital Literacy and Online Child Abuse among Primary School Children in Langata Sub-county, Nairobi City County in Kenya. International and Multidisciplinary Journal of Social Sciences, 10(2), 1-30. doi: 10.17583/rimcis.2021.5566

To link this article: http://doi.org/10.17583/rimcis.2021.5566

PLEASE SCROLL DOWN FOR ARTICLE

The terms and conditions of use are related to the Open Journal System and to Creative Commons Attribution License(CC-BY). 
Sciences Vol. 10 No. 2 July 2021 pp. 1-30

\section{Digital Literacy and Online Child Abuse among Primary School Children in Langata Sub-county, Nairobi City County in Kenya}

Wilkins Ndege Muhingi

Pan Africa Christian University
Mumo Nzau

University of Nairobi

Johnson Nzau Mavole

St. Augustine University of Tanzania

\section{Abstract}

Kenya introduced Digischool to public primary schools to prepare children for today's digital world attracting a cyber-threat landscape. Utilising a descriptive crosssectional design within a concurrent mixed approach, the study examined the relationship between digital literacy intervention and online child abuse among primary school children in Langata sub-county. Targeted, were children between 9 and 17 years from private and public primary schools, teachers, parents and policy makers, and child protection officers. Godden's formula informed purposive and random sampling of 384 respondents, plus a 10\% (423) respondents for Key Informant interviews and focused discussions. Quantitative and qualitative data were analysed using both descriptive and inferential statistics and content analysis with the help of SPSS version 22 and Nvivo version 12 respectively. The study revealed stakeholders intervened in online child abuse at various levels using several strategies. The study revealed a significant relationship between the type of school and exposure online. Since the p-value $(0.000)$ was less than alpha $(0.05)$ and we conclude there was a significant relationship between the type of school and exposure to online child abuse. There is a need for systems thinking and a concerted multi-sectoral approach to the improvement of digital literacy hence protecting children online.

Keywords: digital literacy, online child abuse, Kenya 
Sciences Vol. 10 No. 2 July 2021 pp. 1-30

\section{Educación Alfabetización Digital y Abuso Infantil Online entre Alumnado de Primaria en Langata Sub-county, Nairobi County en Kenya}

Wilkins Ndege Muhingi

Pan Africa Christian University

Johnson Nzau Mavole

St. Augustine University of Tanzania

\author{
Mumo Nzau \\ University of Nairobi
}

\section{Resumen}

Kenia introdujo Digischool en las escuelas primarias públicas para preparar a los niños para el mundo digital actual que atrae un panorama de amenazas cibernéticas. Utilizando un diseño transversal descriptivo dentro de un enfoque mixto concurrente, el estudio examinó la relación entre la intervención de alfabetización digital y el abuso infantil en línea entre los niños de la escuela primaria en el subcondado de Langata. Los beneficiarios fueron niños de entre 9 y 17 años de escuelas primarias públicas y privadas, maestros, padres y encargados de la formulación de políticas, y oficiales de protección infantil. La fórmula de Godden informó un muestreo intencionado y aleatorio de 384 encuestados, más un 10\% (423) encuestados para entrevistas con informantes clave y discusiones enfocadas. Los datos cuantitativos y cualitativos se analizaron utilizando estadísticas descriptivas e inferenciales y análisis de contenido con la ayuda de SPSS versión 22 y Nvivo versión 12 respectivamente. El estudio reveló que las partes interesadas intervinieron en el abuso infantil en línea en varios niveles utilizando varias estrategias. El estudio reveló una relación significativa entre el tipo de escuela y la exposición en línea. Dado que el valor $\mathrm{p}(0,000)$ fue menor que alfa $(0,05)$ y concluimos que hubo una relación significativa entre el tipo de escuela y la exposición al abuso infantil en línea. Existe la necesidad de un pensamiento sistémico y un enfoque multisectorial concertado para mejorar la alfabetización digital y proteger a los niños en línea.

Palabras clave: alfabetitzación digital, abuso infantil online, Kenia 
s well as a vital cornerstone of general education, digital literacy is
one of the guiding forces in the growth of the digital age. In order to
encourage Sustainable Development Goal 4 (SDG)-Quality Education, developing countries have integrated digital literacy into general education, making it an active part of the digital economy for the majority of their people (Urbancikova, Manakova \& Ganna, 2017).

There are two common terms "Digital divide" and "digital inclusion", which relate to connectivity and internet utilization that have gained popularity (Nemer, 2015). The real origin of the term "Digital divide" is not known but it was advanced and began to be widely used in the mid-1990s to describe the disparity between households that have access to the Internet and households that do not have access to the Internet (Light, 2001; Pigato, 2001). However, this divide continues to persist today in the wake of COVID-19 (Aissaoui, 2021). Catalysts for bridging the digital divide on what former US Vice President Gore called "the information superhighway" was the notion of ICTs as global education and economic equalizer (Cerf, 2019). Computers were introduced in college classrooms around the world, and are making their way into primary and secondary schools in wealthy cities including developing countries (Tatnall, 1992; Tatnall \& Davey, 2004). Access to the Internet is seen as a way to change education in profound ways.

Another term "digital inclusion later took a centre stage among media and researchers. This term described the differences that existed between hardware and broadband access, in particular, this was about access to ICT knowledge in the home, the school, and the workplace. These disparities in digital access that remained among poor, undereducated, and racial-ethnic minorities and may affect the quality of life although (Ali, Alam, Taylor \& Rafiq, 2020) observe studies have shown mixed results (Helsper, 2008; Livingstone \& Helsper, 2007). The solution to inclusion is often described as community building, therefore grassroots organizations and community centers began offering access to ICTs through their facilities.

Digital inclusion presupposes that people who are not connected to ICTs want to join the digital society and need assistance in understanding the importance of the technology. Rather than trying to find who was not connected, the notion put forward in digital inclusion was to work toward bringing underserved populations - people in underdeveloped and developing nations; poor, undereducated people and racial-ethnic minorities in the United 
States; and minority populations around the world - into the already existing digital society. The word "inclusion" is perceived as being more forwardthinking than the term "divide" when it comes to describing the state of digital affairs. Despite the shift in terminology and focus, several scholars and organizations around the world remain committed to the concept of the digital divide. In doing so, they have discovered more nuanced approaches to understanding the digital divide. The second wave of digital divide interrogates access as both physical and intellectual, and usage as place and purpose was introduced by Hargittai (2001) by investigating user differences in ICT skills.

According to Bean and Kern (2018), digital literacy is seen in the light of praxeology as school teachers carry out educational practices aimed at reducing risk behaviors facilitated by digital media and most frequently associated with: student cyberbullying (Pyżalski, 2012). The digital environment has been blamed for underutilised opportunities for learning, creativity, and social connectivity (Lomax, Murray \& Pyer, 2018). According to the House of Lords (2017 as cited in Lomax, Murray and Pyer 2018), no child should leave school without a well-rounded understanding of the digital world. Digital literacy concepts have slight differences in reach or focus areas, and their meanings often overlap (Zhang \& Zhu, 2016). Digital literacy is described as "intelligence assembly" by Paul Gilster (1997 as cited in Pool, 1997, p.9) and includes "how to assimilate the information, analyze it, and reintegrate it." Digital literacy refers to the ability of individuals to use skills, knowledge, and understanding to make full use of the opportunities offered by the new media world as well as safeguard themselves from associated risks (Martin, 2005 as cited in Buckingham, 2007):

"Digital literacy is the awareness, attitude and ability of individuals to appropriately use digital tools and facilities to identify, access, manage, integrate, evaluate, analyse and synthesize digital resources, construct new knowledge, create media expressions, and communicate with others, in the context of specific life situations, to enable constructive social action; and to reflect upon this process" (Martin, 2005, p. 135 as cited in Buckingham, 2007). 
Digital literacy can be seen as an umbrella concept that includes elements of other literature that share conceptual grounds with other forms of literacy, such as knowledge literacy that is capable of identifying, finding, assessing and using information (UNESCO, 2018; Cummins, Becker \& Alexander, 2016), media literacy that is, the ability to access, recognize and critically evaluate media messages (Koltay, 2011) and news media literacy. i.e., the ability to apply core media literacy skills to news (Vraga, Tully, Kotcher, Smithson \& Broeckelman-post, 2015; Maksl, Craft, Ashley \& Miller, 2017). Digital literacy skills include but are not limited to Instrumental (or essential or functional), insightful (comprehension, navigation, assessment), and social (communication, disclosure, privacy) (Sonck, Livingstone, Kuiper \& de Haan, 2011). There worldwide recognition of the importance for children to be digitally literate (CoE, 2018; Keeley \& Little, 2017), although there are limited studies on relationship between digital literacy and online safety (Nascimbeni \& Vosloo, 2019).

According to Sonck and de Haan (2014), there are very few longitudinal studies looking at the relationship between digital skills and threats online. Kids, like teenagers, are believed to be able to avoid negative consequences of digital technology by learning digital skills (Rodríguez de Dios, 2018; Sonck \& de Haan, 2014; Sonck, Livingstone, Kuiper \& de Haan, 2011). Besides, research indicates that those with more internet experience or digital capabilities will gain more from online opportunities (Lee \& Chae, 2012; Livingstone \& Helsper, 2010; Nikken \& Schols, 2015; Sonck \& de Haan, 2013). Certain empirical studies, on the contrary, have shown that the more qualified teenagers there are, the more risks they face online (Lee \& Chae, 2012; Leung \& Lee, 2012; Livingstone, Ólafsson, Helsper, LupiáñezVillanueva, Veltri \& Folkvord, 2017; Livingstone \& Helsper, 2010; Sonck \& de Haan, 2013; Staksrud et al., 2013).

According to Joyce, Pham, Stanton Fraser, Payne, Crellin \& McDougall (2014), the history of digital literacy and online education projects has been patchy for example in the UK despite recent calls for a clear curriculum for digital media education since media education aims to teach students how to become critical media users through media analysis and media production (Children's Commissioner, 2017; Hobbs as cited in Polizzi, 2020). Previous research according to Marsh, Hannon, Lewis, \& Ritchie (2017) and Plowman et al. (2012) showed the early establishment of 'digital literacy' in young children (0-8) and learning through home technology. Citing Görzig, and 
Ólafsson (2011), Livingstone, Davidson, Bryce, Batool, Haughton, and Nandi (2017) observed that girls tended to report slightly fewer digital skills than boys and younger children reported considerably fewer skills than older teenagers. Moreover, skills of children with disabilities, who are discriminated against, or who are from disadvantaged backgrounds, vary - some have fewer skills commensurate with their fewer resources or available supports, but others have developed skills partly through facing negative experiences online (Livingstone et al., 2017).

Children's digital literacy changed qualitatively with age for example, at around 9 to 10 years, children were concerned with what was real or not, although they would not discriminate real from fake. At 11 to 13 years children were more concerned with what was fun or even transgressive, irrespective of whether it was trustworthy. Lastly, by 14 to 16 years their increasing maturity led teenagers to refocus on what was more valuable for them or more generally (Livingstone, 2014; Livingstone, Kirwil, Ponte \& Staksrud, 2014). The shift in focus would be brought about by a change in peer and parental relations with the children and had implications for the incidence of online risks encountered by children (Ofcom, 2016). Children's digital literacy was found to increase fairly steadily from age 8 to young adulthood. Also, with increasing age, children gained digital literacy to realise that some but not all search engine results could be trusted (Ofcom, 2016).

A study comparing EU Kids Online and Net Children Go Mobile also showed little change in the levels of children's digital literacy and safety skills since 2010, although children are now better able to manage their privacy settings and to delete their browsing history. On the other hand, the same comparison showed that the proportion of children whose profiles were public had nearly doubled from 11 to $19 \%$ of social network users aged between 9 to 16 , which may reflect the diversification in social networks used (Livingstone et al., 2014). Schools are an important partner in ensuring child protection online (Shipton, 2011). E-safety guidance from schools is particularly helpful for children from under-resourced households where parents lack confidence or expertise concerning digital media (Livingstone, Mascheroni, Dreier, Chaudron \& Lagae, 2015). Whittle, Hamilton-Giachritsis, and Beech (2014) found that support from schools along with support from parents and friends also assisted with the recovery of victims of online grooming and sexual abuse. 
According to Ofcom (2016), e-safety strategies and initiatives schools would use in protecting children online include annual talks, some with members of the police and/or NSPCC representatives, information videos and associated lesson plans: "We saw a video on CBBC about a girl and Direction and she gave out her details and didn't realize." (Girl, 8-9 years old, Nottingham), e-safety pupil representatives: "I am an e-Safety rep at school and we help to tell [others] how to be safe online." (Girl, 8-9 years old, Nottingham), take-home 'contracts' to share with parents to agree to terms of safe internet use and a Safer Internet Day, held once a year, and other campaigns. In studying two primary schools, Shipton (2011) found that the schools preferred developing the critical capabilities of the students rather than employing blanket filters. This was done to ensure that children can manage risks both at school and elsewhere. Aston and Brzyska (2012) further strengthen the argument for developing critical capacities among children by observing that majority of teachers felt that their pupils had the skills and knowledge to use the internet safely in school yet only $58 \%$ felt that the children were similarly equipped to use it safely at home.

Other scholars, Byrne et al. (2016) revealed that high percentages of children had basic digital literacy skills but only about $20 \%$ (on average) used the internet for creative activities (creating blogs, videos, and websites). Studies show that the more digitally literate children become, the more they can gain from the internet while avoiding or coping with online risks (Sonck, Livingstone, Kuiper \& de Haan, 2011). According to Rouchun, Zongkui, Shuailei, Qingqi and Chen (2019, citing Bronfenbrenner, 1989), the family atmosphere is the most critical micro-system that exerts the most significant impact on young children for example socio-economic status as a distal environment. Access to, familiarity with, and skill using mobile devices are a first step in achieving digital literacy. A study showed that most children started using mobile devices in their first year of life, and use was enabled by parents who gave children a device to use and to keep. Three out of four parents gave children a mobile device when doing chores and to keep them calm (Kabali, Irigoyen, Nunez-Davis, Budacki, Mohanty, Leister \& Bonner, 2015). 'Digital literacy' or 'e-skills' is crucial to children's use of the internet. Internet literacy is a capability constitutive to utilizing the advantages of the Internet and as Knobel and Lankshear (2006) assert has a close relationship with participation in cyber-culture. Byrne et al. (2016) observe that the 
creation of online content by children is a means of self-expression as well as an important vehicle for participation in matters that affect them, participation being one of the underlying principles of the UN Convention on the Rights of the Child. A broad concept of Internet literacy refers to the information, skills, and behaviors used in a wide range of digital devices such as smartphones, laptops, PCs, etc. (Taylor \& Dalal, 2014 citing Julian, 2013).

Cyber-safety risks for children when using video sharing platforms, websites, social networking sites, and games include but are not limited to: Exposure to pornography; Violent content; Contact and conduct risks; Cyberbullying and associated low self-esteem and emotional responses; Contact with strangers and online predation; Content and practices that are not age appropriate through viewing media used by older siblings; Identity theft; and Malware (Robinson, 2013 citing Green et al., 2011). The children's limited digital literacy skills increase the potential for harm to them. One report noted children of [primary school] age are particularly challenged in their cognitive and emotional abilities to cope with online risk. It follows then, that these risks increase where adult supervision is inadequate (Baldry, Sorrentino \& Farrington, 2019).

A study by Tomczyk (2019) in the field of digital security in the school and family environment in Poland revealed that digital literacy was necessary, especially in a group of people who are responsible for facilitating digital safety. A good example is parents who are in contact with children all the time and most time give digital devices to children under their care with good reasons or to keep them off so that they can concentrate on their work.

Parents have to ensure an appropriate degree of digital protection at home since previous study revealed a positive relation between socio-economic status and digital literacy Tran et al. (2020). However, a study by Moawad and Ebrahem (2016) reported a negative correlation between adolescents' technology usage and social interaction with their parents pointing out that the more adolescents used technology, the more their social interaction with their parents was affected.

On the other hand, teachers help their students improve their digital literacy (Savage, 2015). Because of the nature of their work, teachers also have a responsibility to create approaches that promote effective media exposure and socialisation. This is only feasible if teachers have sufficient and up-to-date information about the risks emerging from digital media prevalence. Teachers 
particularly teaching in primary school bear particular responsibility for ensuring digital safety (Cortina-Pérez, Gallardo-Vigil, Jiménez-Jiménez \& Trujillo-Torres, 2014). At the educational point, teachers can influence the behaviors of students that would allow them to protect themselves from traditional and non-standard e-threats such as problem Internet usage, cyberbullying, image security, recognition of false information, sexting, copyright infringements, hygiene of digital media navigation, sensitivity to Internet challenges Digital literacy is undergoing constant changes as the information system is undergoing simultaneous transformations. Digital literacy requires not just the technological capacity to use digital media, but also the mechanisms linked to risky behavior awareness.

A study in the UK showed that one would be termed as internet literate when they can: find information confidently, they can send an instant message, fix a problem on their computer or set up an email account or even download music. Internet literate children may also be able to filter or remove a virus from their computer among other activities. Boys were found to be more skilled than girls. For example, when a girl was able to send an instant message, a boy would be able to download music. The study also revealed that internet skills increased with age (Livingstone, Bober, \& Helsper, 2005).

Kenya, with a population of over 48.5 million people (as of 2016), is generally regarded as one of Africa's most technologically advanced nations. According to estimates, about 85 percent of the population is covered by third generation $(3 \mathrm{G})$ technology in 2017 , but only $17.8 \%$ of individuals and 33.7 percent of households have internet access. In addition, Kenya's telecommunications revenues increased from USD 1.32 billion in 2014 to USD 1.65 billion in 2016 (Okyere, 2020 citing ITU, 2018).

\section{Materials and Methods}

The study was carried out in Nairobi City County specifically Langata Subcounty. Langata Sub-county is one of the nine sub-counties in Nairobi City County which is one of the 47 counties in the Republic of Kenya. The SubCounty lies in the South West of Nairobi, bordering Kajiado County to the North. This sub-county has four divisions and eight wards namely: Karen, Hardy, Lenana, Nairobi West, Olympic, Mugumuini, Bomas, and South C (County, 2018). This study site was selected because of its accessibility to 
cyber cafes and high-speed Internet and the availability of many schools that had very well equipped computer labs and ICT Innovation Centres and good internet connection. It was also preferred because it housed the various levels of population in terms of socio-economic status comprising of the high class, the middle class, and the low class which is not characteristic of the other subcounties within Nairobi City County. This sub-county also had several Information technology innovation centres.

The researchers utilized a descriptive cross-sectional design within a concurrent mixed approach collecting and analysing both qualitative and quantitative data at the same time (McCusker \& Gunaydin, 2015). The study targeted children between ages 9 years and 17 years old from selected private and public primary schools in Langata Sub-county, teachers, parents and policy makers within the Department of children services and Directorate of Criminal Investigation. Godden's formula informed the sample size determination of 384 respondents, plus $10 \%$ of the sample size to cater for non-response by respondents making a total of 423 respondents. Key Informant interviews were also carried out targeting 9 parents, 9 Key informant teacher respondents, 2 Key informant Child protection officer respondents all sampled purposively.

The researchers utilised simple random, stratified purposive sampling, stratified sampling, convenience, and purposive sampling designs. Three schools were selected from three regions within Langata Sub-county which included: Karen, South C, and Mugumuini wards. The study sought both empirical data and secondary data from published sources like general and specific search engines. Interviews and focused group discussions were carried (5 FGDs) which enabled the collection of data using interview guides, questionnaires, and FGD guides tools. Quantitative data were analysed using both descriptive and inferential statistics with the help of SPSS version 22 . Bivariate and multivariate statistics were applied to examine relationships between the independent and dependent variables. Data were transformed to enable further inferential statistics to relate variables and help test hypotheses. Findings were presented using graphs, frequencies, charts, and tables. Qualitative data were analysed using content analysis with the help of Nvivo version 12 and presented in narrative and map forms. Informed written consent was sought in writing and verbally from all respondents including teachers, parents, children and protection officers following the right 
procedure, who were prepared in advance on the nature of questioning including the degree of sensitivity of the subject. Parents and guardians were approached to give consent on behalf of their children. All participants were allowed to take part in the study. However, they were informed that if they wished to withdraw from the study at some point then they were allowed.

Ultimate confidentiality was observed in regards to the individuals sampled for purposes of data collection, especially regarding the case studies. No information provided by the children, teachers, parents, child protection officers, and government officials was shared with any other person for any purpose other than supervisors and where was required so to prepare this research report. Lastly, the researcher disseminated research findings as planned.

\section{Results and Discussion}

This section presents characteristics of the demographic profile of the respondents. Besides, the researchers present the type of schools respondents attended, the risky actions by respondents when they go online and the categories of cyberbullying and abuse experienced while online. Finally presented was digital literacy that was measured using twenty-five items among the respondents.

Table 1.

Distribution by response rate

\begin{tabular}{lcc}
\hline & Frequency & Percentage \\
\hline Complete questionnaires & 370 & $87 \%$ \\
Not Completed questionnaires & 53 & $13 \%$ \\
\hline Total & $\mathbf{4 2 3}$ & $\mathbf{1 0 0} \%$ \\
\hline
\end{tabular}

Source (Field data, 2019)

The researchers purposively selected 12 primary schools, two private schools and two public schools per ward in the selected three wards out of the eight that existed from within Langata Sub-county in Nairobi. The total sample was 423 pupils, out of which 370 successfully filled and returned questionnaires. The researchers invited children respondents aged 9 years to 17 years enrolled in primary public and private schools in Langata SubCounty in Nairobi City County in Kenya to participate in the study. 


\section{Muhingi, Mavole \& Nzau-Digital Literacy and Online Child Abuse}

Questionnaires were administered to the children and out of the 423 questionnaires, $53(13 \%)$ of the children either refused to or did not return their questionnaires. A good number 370 (87\%) filled the questionnaires successfully and returned. The questionnaires that were filled successfully were sufficient for analysis for a response rate. That shows that automatically the study sample remained 370 respondents.

\section{Demographic Profile of Respondents}

This section presents the characteristics of the demographic profile of the respondents. The characteristics of the children were, age, gender, class, type of school, residence and level of education of parents.

Of the 370 respondents, $49.2 \%$ were girls while $188(50.2 \%)$ were boys. The findings revealed that the highest number of those who successfully filled and returned questionnaires were class six pupils forming a $22.2 \%$ (82) as shown in table 3 . The study found that $91(24.6 \%)$ were 12 years old followed by $78(21.1 \%) 61(16.5 \%)$ were 13 years old as the least number. This may be attributed to the fact that most pupils after age 13 may have transited to secondary school. The highest number of respondents $38.4 \%$ (142) resided in the Mugumuini area followed by the Karen area $37.3 \%$ (138) and only $24.3 \%$ (90) resided in South C because the response rate was low in South C ward.

The study showed that $175(47.3 \%)$ pupils in public schools accessed the internet while $191(51.6 \%)$ in private schools accessed the internet. This revealed that a higher number of children in private schools access the internet compared to those in public schools. This was because in private schools children used the internet even for their homework assignments. A very small but equal number of $2(0.5 \%)$ respondents did not access the internet. Children from private schools were from higher social economic status and therefore their parents afford internet and internet access gadgets. According to Rouchun, Zongkui, Shuailei, Qingqi and Chen (2019 citing Bronfenbrenner, 1989), the family atmosphere is the most critical micro-system that exerts the most significant impact on young children for example socio-economic status as a distal environment. Earlier survey results showed that families with elevated socio-economic status had more Internet access devices and more Internet access resources for children (Lenhart et al., 2001). The findings concur with a related study by Tran et al. (2020) revealing a positive 
International and Multidisciplinary Journal of Social Sciences, 10(2) 13

correlation between family socioeconomic factors and students' digital literacy.

Table 2.

Distribution by demographic information

\begin{tabular}{|c|c|c|c|}
\hline Variable & Values & Frequency & Percent \\
\hline \multirow[t]{3}{*}{ Gender } & Female & 182 & 49.2 \\
\hline & Male & 188 & 50.8 \\
\hline & Total & 370 & 100 \\
\hline \multirow[t]{6}{*}{ Age } & 9 & 69 & 18.6 \\
\hline & 10 & 71 & 19.2 \\
\hline & 11 & 78 & 21.1 \\
\hline & 12 & 91 & 24.6 \\
\hline & 13 & 61 & 16.5 \\
\hline & Total & 370 & 100 \\
\hline \multirow[t]{6}{*}{ Class } & 4 & 76 & 20.5 \\
\hline & 5 & 75 & 20.3 \\
\hline & 6 & 82 & 22.2 \\
\hline & 7 & 72 & 19.5 \\
\hline & 8 & 65 & 17.6 \\
\hline & Total & 370 & 100 \\
\hline \multirow[t]{3}{*}{ Type of School } & Public & 176 & 47.6 \\
\hline & Private & 194 & 52.4 \\
\hline & Total & 370 & 100 \\
\hline \multirow[t]{4}{*}{ Residence } & Karen & 142 & 38.4 \\
\hline & Mugumuini & 139 & 37.6 \\
\hline & South C & 89 & 24.1 \\
\hline & Total & 370 & 100 \\
\hline Parent's Level of & Less than high school & 18 & 4.9 \\
\hline \multirow[t]{4}{*}{ Education } & High School & 61 & 16.5 \\
\hline & Some College & 119 & 32.2 \\
\hline & College + & 172 & 46.5 \\
\hline & Total & 370 & 100 \\
\hline \multirow[t]{4}{*}{ Location of the School } & Karen & 138 & 37.3 \\
\hline & Mugumuini & 142 & 38.4 \\
\hline & South C & 90 & 24.3 \\
\hline & Total & 370 & 100 \\
\hline
\end{tabular}

Source (Field data, 2019) 
14 Muhingi, Mavole \& Nzau-Digital Literacy and Online Child Abuse

Table 3.

Distribution by Type of School and Access to internet $(n=370)$

Type of school * Access to internet Crosstabulation

Count

\begin{tabular}{llccc}
\hline & & \multicolumn{3}{c}{ Access to internet } \\
Type of school & Yes & No & Total \\
& Private & 175 & 2 & 177 \\
Total & 191 & 2 & 193 \\
\hline
\end{tabular}

Source (Field data, 2019)

Findings on Digital Literacy Interventions Influence on Online Child Abuse

Table 4.

Distribution by Risky online Actions

\begin{tabular}{lcc}
\hline & Frequency & Percent \\
\hline Chatting & 76 & 20.5 \\
Watching video & 130 & 35.1 \\
Photos uploading & 82 & 22.2 \\
Listening to music & 24 & 6.5 \\
Gaming & 21 & 5.7 \\
Other & 37 & 10.0 \\
\hline Total & 370 & 100.0 \\
\hline
\end{tabular}

Source (Field data, 2019)

A high number of respondents $35.1 \%$ (130) considered watching videos as the riskiest online activities mentioning specifically pornographic videos. The online action considered less risky was gaming at 5.7\% (21). This means that the children had experienced abuse through some videos. They reported having watched music video clips they considered offensive.

Almost half the respondents $48.6 \%$ (180) had experienced bullying that involved strangers sharing pictures and videos with them. Some children 27 $\%$ reported having experienced abuse through text messages through phones. Whatsapp and e-mail recorded the lowest 5.4\% (20) considering it not easily used for cyberbullying. Only $5.4 \%$ had experienced abuse through the e-mail. 
Most of the children did not either know how to use mails or use mails often, the reason for a low percentage. Few $5.4 \%$ had experienced abuse through WhatsApp since it was a smartphone application and few of them had their phones. Those who had experienced abuse through WhatsApp agreed to have shared with siblings or those who owned phones. Others cited Facebook as a site where they experienced abuse.

Table 5.

Categories of Cyberbullying experienced $(n=370)$

\begin{tabular}{lcc}
\hline & Frequency & Percent \\
\hline Text message & 100 & 27.0 \\
Email & 20 & 5.4 \\
Phone call & 50 & 13.5 \\
Picture or video clip & 180 & 48.6 \\
WhatsApp & 20 & 5.4 \\
\hline Total & 370 & 100.0 \\
\hline
\end{tabular}

Source (Field data, 2019)

A child protection officer disclosed children were at risk on the internet. The children were at risks of exposure online for example:

"When children access the internet they play games like "Blue Whales" which may be disastrous. A good example is when children end up committing suicide." When children accept friend requests on social media and other platforms that exist it is risky because some are abducted mostly because they are interacting with people who enjoy anonymity. It is scary that some pose as children and children easily trust and start engaging them. These online strangers ask children for information and family details which makes the children more vulnerable to trafficking." (Respondent 3, $7^{\text {th }}$, March, 2019)

Digital literacy was measured using twenty-five items among the respondents and the results revealed the following: Findings on whether they frequently used the internet for schoolwork, 165 (44.6) strongly disagreed while $12(3.2 \%)$ disagreed showing that more than half did not frequently use 
the internet at school. Respondents reported they played internet games on their own with $65(17.6 \%)$ agreeing and 141 (38.1\%) strongly agreeing. About $30 \%$ did not watch video clips on the internet as $80(21.6 \%)$ strongly disagreed and $68(18.4 \%)$ disagrees. On whether they read/watched the news on the internet, 38 (10.3\%) agreed while 102 (27.6\%) strongly agreed. Respondents agreed that they downloaded music or films as 55 (14.9\%) agreed while 109 (29.5) strongly agreed.

\section{Table 6.}

Distribution by digital literacy $(n=370)$

\begin{tabular}{|c|c|c|c|c|c|}
\hline Statement & SD & D & $\mathbf{N}$ & $\mathbf{A}$ & SA \\
\hline I frequently use the internet for schoolwork & $165(44.6)$ & $12(3.2)$ & $80(21.6)$ & $35(9.5)$ & $78(21.1)$ \\
\hline I play internet games on my own & $33(8.9)$ & $42(11.4)$ & $89(24.1)$ & $65(17.6)$ & $141(38.1)$ \\
\hline I watched video clips on internet & $80(21.6)$ & $68(18.4)$ & $88(23.8)$ & $54(14.6)$ & $80(21.6)$ \\
\hline I read/watch the news on the internet & $108(29.2)$ & $17(4.6)$ & $105(28.4)$ & $38(10.3)$ & $102(27.6)$ \\
\hline I download music or films & $77(20.8)$ & $41(11.1)$ & $88(23.8)$ & $55(14.9)$ & $109(29.5)$ \\
\hline I usually use instant messaging & $101(27.3)$ & $21(5.7)$ & $128(34.6)$ & $59(15.9)$ & $61(16.5)$ \\
\hline I visit social networking sites & $148(40.0)$ & $31(8.4)$ & $83(22.4)$ & $40(10.8)$ & $68(18.4)$ \\
\hline I send/receive emails & $148(40.0)$ & $29(7.8)$ & $114(30.8)$ & $42(11.4)$ & $37(10.0)$ \\
\hline I played games with other people online & $99(26.8)$ & $39(10.5)$ & $129(34.9)$ & $58(15.7)$ & $45(12.2)$ \\
\hline I usually use a webcam & $123(33.2)$ & $29(7.8)$ & $115(31.1)$ & $50(13.5)$ & $53(14.3)$ \\
\hline I frequently visit a chatroom & $127(34.3)$ & $30(8.1)$ & $121(32.7)$ & $28(7.6)$ & $64(17.3)$ \\
\hline $\begin{array}{l}\text { I put or post photos, videos, or music to share with } \\
\text { others }\end{array}$ & $99(26.8)$ & $45(12.2)$ & $86(23.2)$ & $45(12.2)$ & $95(25.7)$ \\
\hline I put or post messages on a website & $161(43.5)$ & $34(9.2)$ & $109(29.5)$ & $33(8.9)$ & $33(8.9)$ \\
\hline I always create characters, pets or avatars & $165(44.6)$ & $49(13.2)$ & $110(29.7)$ & $23(6.2)$ & $23(6.2)$ \\
\hline I often use file sharing sites & $160(43.2)$ & $25(6.8)$ & $129(34.9)$ & $30(8.1)$ & $26(7.0)$ \\
\hline I spend time in a virtual world & $138(37.3)$ & $74(20.0)$ & $109(29.5)$ & $14(3.8)$ & $35(9.5)$ \\
\hline I write blogs or online diaries & $147(39.7)$ & $45(12.2)$ & $127(34.3)$ & $21(5.7)$ & $30(8.1)$ \\
\hline I am able to bookmark a website & $92(24.9)$ & $62(16.8)$ & $101(27.3)$ & $62(16.8)$ & $53(14.3)$ \\
\hline $\begin{array}{l}\text { I am able to block messages from someone I don't } \\
\text { want to hear from }\end{array}$ & $105(28.4)$ & $35(9.5)$ & $143(38.6)$ & $34(9.2)$ & $53(14.3)$ \\
\hline $\begin{array}{l}\text { I am able to change privacy settings on a social } \\
\text { networking profile }\end{array}$ & $123(33.2)$ & $32(8.6)$ & $137(37.1)$ & $31(8.4)$ & $47(12.7)$ \\
\hline $\begin{array}{l}\text { I can delete the record of which sites you have } \\
\text { visited }\end{array}$ & $83(22.4)$ & $87(23.5)$ & $103(27.8)$ & $55(14.9)$ & $42(11.4)$ \\
\hline I can block unwanted adverts or junk mail/spam & $133(35.9)$ & $28(7.6)$ & $126(34.1)$ & $32(8.6)$ & $51(13.8)$ \\
\hline I can change filter preferences & $117(31.6)$ & $33(8.9)$ & $140(37.8)$ & $30(8.1)$ & $50(13.5)$ \\
\hline $\begin{array}{l}\text { I am able to find information on how to use the } \\
\text { internet safely }\end{array}$ & $100(27.0)$ & $27(7.3)$ & $109(29.5)$ & $40(10.8)$ & $94(25.4)$ \\
\hline $\begin{array}{l}\text { I am able to compare different websites to decide if } \\
\text { information is true }\end{array}$ & $139(37.6)$ & $25(6.8)$ & $101(27.3)$ & $42(11.4)$ & $63(17.0)$ \\
\hline
\end{tabular}

Source (Field data, 2019)

The children were able to use instant messaging for 59 (15.9\%) agreed while $61(16.5 \%)$ strongly agreed. Response on whether the children visited social networking sites. More than half of the respondents, $148(40.0 \%)$ 
strongly disagreed and $31(8.4 \%)$ disagreed that they sent/received emails. The study revealed that of those who participated in, children did not play games online much with less than half, $148(40.0 \%)$ strongly disagreeing and $29(7.8 \%)$ disagreeing. On whether they played games with other people online 99 (26.8) strongly disagree and 39 (10.5\%) disagree. On the use of a webcam $123(33.2 \%)$ strongly disagreed and $29(7.8 \%)$ disagreed. They did not agree to frequently visit a chatroom $127(34.3 \%)$ strongly disagreed and $30(8.1 \%)$ disagreed.

Less than half of the respondents did not put or post photos, videos, or music to share with others 99 (26.8\%) strongly disagreed while $45(12.2 \%)$ disagreed. More than half of respondents did not put or post messages on a website whereby 161 (43.5\%) strongly disagreed and $34(9.2 \%)$ disagreed I always create characters, pets or avatars 165 (44.6) SD and 49 (13.2) D. Slightly less than half the respondents did not often use file sharing sites as 160 (43.2) strongly disagreed while 25 (6.8\%) disagreed. Half of the respondents disagreed with spending time in a virtual world as $138(37.3 \%)$ strongly disagreed and $74(20.0 \%)$ disagreed. Children did not have the skill of writing blogs or online diaries and also bookmarking a website as 147 (39.7\%) strongly disagreed and $45(12.2 \%)$ disagreed and 92 (24.9\%) strongly disagree and $62(16.8 \%)$ disagree respectively. Children were not able to block messages from someone they did not want to hear from, $105(28.4 \%)$ strongly disagreed, and $35(9.5 \%)$ disagreed. Quite a good number 143 $(38.6 \%)$ were undecided for they were neutral. They also reported they were neither able to change privacy settings on a social networking profile, 123 $(33.2 \%)$ strongly disagreed while $32(8.6 \%)$ disagreed nor delete the record of which sites they had visited, 83 (22.4\%) strongly disagreed, and 87 (23.5\%) disagreed.

The findings showed that respondents could not block unwanted adverts or junk mail/spam, 133 (35.9\%) strongly disagreed, and 28 (7.6\%) disagreed. Children disagreed with being able to change filter preferences, $117(31.6 \%)$ strongly disagreed, and 33 (8.9\%) disagreed. Again they were not able to find information on how to use the internet safely, 100 (27.0\%) strongly disagreed, and $27(7.3 \%)$ disagreed. Finally, respondents were unable to compare different websites to decide if the information was true, 139 (37.6\%) strongly disagreed, and 25 (6.8\%) disagreed. 
The findings revealed that children were limited in skills concerning digital literacy and were therefore highly internet illiterate and this would either expose them to online abuse or even would shield them from predators since they were not so much exposed to internet risk. In comparison to what was indicated by prior literature, kids, like teenagers, are believed to be able to avoid negative consequences of digital technology by learning digital skills (Rodríguez de Dios, 2018; Sonck \& de Haan, 2014; Sonck, Livingstone, Kuiper \& de Haan, 2011). Besides, research indicates that those with more internet experience or digital capabilities will gain more from online opportunities (Lee \& Chae, 2012; Livingstone \& Helsper, 2010; Nikken \& Schols, 2015; Sonck \& de Haan, 2013). Certain empirical studies, on the contrary, have shown that the more qualified teenagers there are, the more risks they face online (Lee \& Chae, 2012; Leung \& Lee, 2012; Livingstone et al., 2017; Livingstone \& Helsper, 2010; Sonck \& de Haan, 2013).

Online coping is one-way children can deal with online child abuse-related encounters. It can be defined as 'internet-specific problem-solving strategies children adopt after a negative experience online' (Vandoninck et al., 2013, p. 61). A study by the EU Kids Online identified three main coping strategies: passive responses, that include fatalistic (stop using the internet for while) and self-accusatory responses (feeling guilty about what happened); proactive responses (such as reporting inappropriate content and contact, blocking the unwanted contact, etc.); and communicative responses (talking with parents, peers, teachers or other trusted adults about what happened) (Livingstone, Haddon, Görzig, \& Ólafsson, 2011). Learning how to cope with negative experiences effectively is one of the most effective responses for any particular situation which is part of the process of building resilience among internet users (Vandoninck et al., 2013). Responding to online risks by seeking support from social networks is the most common coping strategy adopted by children, although in most cases they tend to combine two strategies (Livingstone et al., 2011).

\section{Pearson Correlation}

Correlations estimate the strength of the linear relationship between two (and only two) variables. Correlation coefficients range from -1.0 (a perfect negative correlation) to positive 1.0 (a perfect positive correlation). The closer 
correlation coefficients get to -1.0 or 1.0 , the stronger the correlation. The closer a correlation coefficient gets to zero, the weaker the correlation is between the two variables. Ordinal or ratio data (or a combination) must be used. After testing the hypothesis stated below, the researcher obtained the following results as interpreted them as shown:

$\mathrm{H}_{0}$ There is no relationship between exposure to the internet and digital literacy

The correlation coefficient for exposure to the internet and digital online literacy was 0.041 . The number of respondents in the sample answering both items is 370 and 376 respectively. The p-value for this correlation coefficient was .431. There is a weak positive relationship between exposure to the internet and children internet digital literacy.

Table 7.

Distribution by Correlation between exposure to the internet and digital literacy

\begin{tabular}{llcc}
\hline & & Mexposure & Mdigitallit \\
\hline Mexposu & Pearson & 1 & .041 \\
re & Correlation & & .431 \\
& Sig. (2-tailed) & & 370 \\
& N & 370 & 1 \\
Mdigitall & Pearson & .041 & \\
it & Correlation & .431 & 370 \\
& Sig. (2-tailed) & 370 & \\
\hline
\end{tabular}

Source (Field data, 2019)

Since $\mathrm{p}(0.431)>$ alpha 0.05 , we fail to reject the null of no relationship and conclude that the relationship is not statistically significant. The researcher used two-tailed because the direction was not known earlier. As shown in the table, a p-value of .431 indicates that the correlation is not significant and the two variables exposure and digital literacy are not linearly related. This implied that even if the children are exposed to the internet that alone does not improve much of their digital or internet literacy hence there is a need for them to be guided and assisted to navigate while using the internet for their security. It can further be interpreted that children exposed to the 
internet would fall prey to predators and abusers whose tricks are dynamic and they are always ahead of the children. This is in agreement with Krueger (2002) who discovered Internet skills (the ability to access the web) was the most significant indicator of online participation) and deal with emails. People who are more familiar with the Internet and have good social skills and communication skills would benefit more from internet use, consistent with the Rich-Get-Richer-Theory (Kraut et al., 2002).

Table 8.

Distribution by children's knowledge about the Internet in comparison to Parents

\begin{tabular}{lcc}
\hline & Frequency & Percent \\
\hline Not true & 258 & 69.7 \\
A bit true & 64 & 17.3 \\
Very true & 33 & 8.9 \\
Other & 15 & 4.1 \\
\hline Total & 370 & 100.0 \\
\hline
\end{tabular}

Source: (Field data, 2019)

Comparing their knowledge with their parents about the use of the internet regarding the statement that 'I know more about the internet than my parents', more than half $258(69.7 \%)$ of the children revealed it was not true that they were more knowledgeable than their parents. Other respondents, $64(17.3 \%)$ said it was a bit true,' $33(8.9 \%)$ agreed it was true their parents were more knowledgeable than them on matters internet and $15(4.1 \%)$ gave other reasons. This concurs with a study by Livingstone et al. (2015) on how parents of young children manage digital devices at home. Children don't believe that they have more internet abilities than their parents (Livingstone et al., 2015). This meant children had confidence in their parents guiding them on how to use the internet and keep safe. However, this is contrary to a study by Moawad and Ebrahem (2016) that reported a negative correlation between adolescents' technology usage and social interaction with their parents pointing out that the more adolescents used technology, the more their social interaction with their parents was affected. This raises the question of interaction and guidance provided by parents as indicated in this study although this study sample included younger children who may be more trusting to their parents compared to adolescents who listen to their peers more. 
Table 9.

Distribution by Children's knowledge about the Internet than teachers +

\begin{tabular}{lcc}
\hline & Frequency & Percent \\
\hline Not true & 120 & 32.4 \\
A bit true & 180 & 48.6 \\
Very true & 30 & 8.1 \\
Other & 40 & 10.8 \\
\hline Total & 370 & 100.0 \\
\hline
\end{tabular}

Source (Field data, 2019)

Comparing their knowledge with their parents about the use of the internet regarding the statement that 'I know more about the internet than my parents', almost half of the respondents $48.6 \%$ (180) accepted that they knew about the internet than their teachers. Respondents thought that they knew a lot of things about the internet meaning they were confident in their teachers guiding and protecting them while using the internet. A further $32.4 \%$ (120) respondents felt that it was not true that they know more about the internet while a small percentage $8.1 \%$ (30) thought it was not true they knew a lot about the internet. The reason being that they were either not accessing the internet, they were not digitally literate or they were not confident enough.

\section{Conclusion}

Access to cyber-space is no longer a luxury, but an everyday activity for many teachers and learners in the school environment, at home and other environments like cyber. This study found there was early access, early exposure, and early adoption of mobile media devices among young children in an urban, low-income, moderate, and high-income community. Online child abuse is today recognised as a global phenomenon since the internet has been found to have a powerful impact on the lives of children throughout the world. This would continue to grow and evolve. While Internet access and child usage were highest in industrialized countries, the global pace of web access and broadband penetration, and the exponential uptake of mobile phone technologies, coupled with increasing capacities and decreasing costs, means that the rest of the world is beginning to catch up in the next few years, 
it is anticipated that the most dramatic changes will occur in low- and middleincome countries.

Based on the findings of this study the researchers concluded that the responsibility of online child protection was for every stakeholder including the state, parents, teachers, citizens, netizens, and children themselves. It was also concluded that training and the creation of awareness were important elements to consider in protecting children online. The study revealed low skills among parents and teachers on internet matters yet children looked up to them and believed they would guide them in remaining safe online. Children were found to be digitally literate. Digital literacy helped children to remain safe as well as exposing them to internet-related risks as was revealed by other studies.

Only a small proportion of contemporary adults had access to ICT when they were children, particularly the tools that have facilitated the revolution in interaction and communication This has probably affected the ability of adults to understand and empathize with the ways children and young people use the Internet, mobile phones and other new technologies. This may be especially true in societies where children's social activity, particularly that of adolescents, has been under fairly direct parental observation or control.

\section{Recommendations}

The government needs to develop strategies through the Ministry of Education to create institutional capacity to respond to online child abuse to educate minors in the responsible use of ICT. Moreover, programs for the prevention of cyberbullying should also integrate issues related to education about sexting and sexual solicitation among other harmful online child abuse issues. Holistic intervention concerning the different risks found on the Internet is also necessary following the fast and dynamic nature of the growth, accessibility, and availability of the internet which people are exposed to as early as 4 months. Moreover, sexual education programs in schools should address sexting, as it seems to be a new avenue through which adolescents express their sexuality. Besides, educators particularly teachers and parents should be informed about Internet risks and how to protect their children to educate their children on the responsible use of ICT with emphasis on digital skills. 
The onus is on governments and the private sector to ensure that protection is integrated into promoting the expansion of access and the positive benefits the Internet brings. Cyber security awareness and training ought to be a top priority for all African states. This should be cross-cutting from the vulnerable sector or people in the society, school-going children, families, industry captains, critical national infrastructure handlers, government officials, and the entire African continent with its unique needs.

The government of Kenya through the Communications Authority to first track: Establishing a database on reported cybercrime cases affecting children; Commissioning of national research on Online Child Sexual Exploitation, which once completed would provide a more reliable and full picture of OCSE in Kenya; Developing a training curriculum that could be used to train stakeholders on online safety of children and related risks and Developing a National Child Online Framework Strategy. The government needs to put in place the policy, legal and regulatory framework which is also important. That would require the involvement and support of the political leadership and goodwill at the very highest level. The lawmakers must be well trained and sensitised to help implement legislation that addresses cyber threats at all levels.

There is a need to address online child abuse at the continental level. African countries need strong Information and Computer Technology institutions. This may be utilised to train cyber security experts in system administration, security audit, forensic investigation, information security, and software development to deal with the future challenges of cybercrime.

\section{References}

Aissaoui, N. (2021). The digital divide: a literature review and some directions for future research in light of COVID-19. Global Knowledge, Memory and Communication, Online first. https://doi.org/10.1108/GKMC-06-2020-0075

Ali, M. A., Alam, K., Taylor, B., \& Rafiq, S. (2020). Does digital inclusion affect quality of life? Evidence from Australian household panel data. Telematics and Informatics, 51, 101405. https://doi.org/10.1016/j.tele.2020.101405 
Aston, H., \& Brzyska, B. (2012). Protecting children online: teachers' perspectives on eSafety. National Foundation for Educational Research.

Baldry, A. C., Sorrentino, A., \& Farrington, D. P. (2019). Cyberbullying and cybervictimization versus parental supervision, monitoring and control of adolescents' online activities. Children and Youth Services Review, 96, 302-307.

https://doi.org/10.1016/j.childyouth.2018.11.058

Bean, R. M., \& Kern, D. (2018). Multiple roles of specialized literacy professionals: The ILA 2017 standards. The Reading Teacher, 71(5), 615-621. https://doi.org/10.1002/trtr.1671

Buckingham, D. (2007). Youth, identity, and digital media. MIT Press.

Byrne, J., Kardefelt-Winther, D., Livingstone, S., \& Stoilova, M. (2016). Global kids online: research synthesis 2015-2016. UNICEF Office of Research Innocenti and London School of Economics and Political Science.

Cerf, V. G. (2019). Hazards of the information superhighway. Communications of the ACM, 62(11), 5. https://doi.org/10.1145/3364216

Children's Commissioner (2017). Growing Up Digital. A report of the growing up digital task force. Available online at:

https://www.childrenscommissioner.gov.uk/publication/growing-updigital

Cortina-Pérez, B., Gallardo-Vigil, M. Á., Jiménez-Jiménez, M. Á., \& Trujillo-Torres, J. M. (2014). Digital illiteracy: a challenge for 21st century teachers/El analfabetismo digital: un reto de los docentes del siglo XXI. Cultura y Educación, 26(2), 231-264. https://doi.org/10.1080/11356405.2014.935108

County, N. C. (2018). County integrated development plan (CIDP) 20182022. Nairobi: NCC.

Cummins, M., Becker, S. A., \& Alexander, B. (2016). NMC Horizon Project Strategic Brief on Digital Literacy. The New Media Consortium.

Hargittai, E. (2001). Second-level digital divide: Mapping differences in people's online skills. arXiv preprint cs $/ 0109068$. 
Helsper, E. (2008). Digital inclusion: An analysis of social disadvantage and the information society. Department for Communities and Local Government.

Joyce, C., Pham, H., Stanton Fraser, D., Payne, S., Crellin, D., \& McDougall, S. (2014, June). Building an internet of school things ecosystem: a national collaborative experience. In Proceedings of the 2014 conference on Interaction design and children (pp. 289292).

Kabali, H. K., Irigoyen, M. M., Nunez-Davis, R., Budacki, J. G., Mohanty, S. H., Leister, K. P., \& Bonner, R. L. (2015). Exposure and use of mobile media devices by young children. Pediatrics, 136(6), 10441050. https://doi.org/10.1542/peds.2015-2151

Keeley, B., \& Little, C. (2017). The State of the Worlds Children 2017:

Children in a Digital World. UNICEF. 3 United Nations Plaza, New York, NY 10017.

Knobel, M., \& Lankshear, C. (2006). Digital literacy and digital literacies: Policy, pedagogy and research considerations for education. Nordic Journal of Digital Literacy, 1(01), 12-24.

Koltay, T. (2011). The media and the literacies: Media literacy, information literacy, digital literacy. Media, Culture \& Society, 33(2), 211-221. https://doi.org/10.1177/0163443710393382 Kraut, R., Kiesler, S., Boneva, B., Cummings, J., Helgeson, V., \& Crawford, A. (2002). Internet paradox revisited. Journal of Social Issues, 58(1), 49-74. https://doi.org/10.1111/1540-4560.00248

Krueger, B. S. (2002). Assessing the potential of Internet political participation in the United States: A resource approach. American Politics Research, 30(5), 476-498.

https://doi.org/10.1177/1532673X02030005002

Lee, S. J., \& Chae, Y. G. (2012). Balancing participation and risks in children's internet use: The role of internet literacy and parental mediation. Cyberpsychology, Behavior, and Social Networking, 15(5), 257-262.

https://doi.org/10.1089/cyber.2011.0552

Lenhart, A., Simon, M., \& Graziano, M. (2001). The Internet and Education: Findings of the Pew Internet \& American Life Project. Pew Internet and American Life Project, Washington, DC. 
Leung, L., \& Lee, P. S. (2012). The influences of information literacy, internet addiction and parenting styles on internet risks. New Media \& Society, 14(1), 117-136. https://doi.org/

$10.1177 / 1461444811410406$

Light, J. (2001). Rethinking the digital divide. Harvard Educational Review, 71(4), 709-734.

https://doi.org/10.17763/haer.71.4.342×36742j2w4q82

Livingstone, S., Bober, M., \& Helsper, E. J. (2005). Active participation or just more information? Young people's take-up of opportunities to act and interact on the Internet. Information, Community \& Society, 8(3), 287-314.

Livingstone, S., Davidson, J., Bryce, J., Batool, S., Haughton, C., \& Nandi, A. (2017). Children's online activities, risks and safety: a literature review by the UKCCIS evidence group. UK Council for Internet Safety.

Livingstone, S., Haddon, L., Görzig, A., \& Ólafsson, K. (2011). EU kids online II: Final report 2011.

Livingstone, S., \& Helsper, E. (2007). Gradations in digital inclusion:

Children, young people and the digital divide. New Media \& Society, 9(4), 671-696. https://doi.org/10.1177/1461444807080335

Livingstone, S., \& Helsper, E. (2010). Balancing opportunities and risks in teenagers' use of the internet: The role of online skills and internet self-efficacy. New Media \& Society, 12(2), 309-329. https://doi.org/ 10.1177/1461444809342697

Livingstone, S., Kirwil, L., Ponte, C., \& Staksrud, E. (2014). In their own words: What bothers children online? European Journal of Communication, 29(3), 271-288.

https://doi.org/10.1177/0267323114521045

Livingstone, S., Mascheroni, G., Dreier, M., Chaudron, S., \& Lagae, K. (2015). How parents of young children manage digital devices at home: The role of income, education and parental style. EU Kids Online, LSE.

Livingstone, S., Ólafsson, K., Helsper, E. J., Lupiáñez-Villanueva, F., Veltri, G. A., \& Folkvord, F. (2017). Maximizing opportunities and minimizing risks for children online: The role of digital skills in 
emerging strategies of parental mediation. Journal of

Communication, 67(1), 82-105. https://doi.org/ 10.1111/jcom.12277

Lomax, H., Murray, J., \& Pyer, M. (2018). Digital lives: Children's Perspectives.

Maksl, A., Craft, S., Ashley, S., \& Miller, D. (2017). The usefulness of a news media literacy measure in evaluating a news literacy curriculum. Journalism \& Mass Communication Educator, 72(2), 228-241. https://doi.org/10.1177/1077695816651970

Marsh, J., Hannon, P., Lewis, M., \& Ritchie, L. (2017). Young children's initiation into family literacy practices in the digital age. Journal of Early Childhood Research, 15(1), 47-60. https://doi.org/10.1177/1476718X15582095

McCusker, K., \& Gunaydin, S. (2015). Research using qualitative, quantitative or mixed methods and choice based on the research. Perfusion, 30(7), 537-542.

https://doi.org/10.1177/0267659114559116

Moawad, G. E., \& Ebrahem, G. G. S. (2016). The Relationship between Use of Technology and Parent-Adolescents Social Relationship. Journal of Education and Practice, 7(14), 168-178.

Nascimbeni, F., \& Vosloo, S. (2019). Digital literacy for children: Exploring definitions and frameworks. Scoping Paper, 01.

Nemer, D. (2015). From digital divide to digital inclusion and beyond: A positional review. The Journal of Community Informatics, 11(1). https://doi.org/10.15353/joci.v11i1.2857

Nikken, P., \& Schols, M. (2015). How and why parents guide the media use of young children. Journal of Child and Family Studies, 24(11), 3423-3435. https://doi.org/10.1007/s10826-015-0144-4

Ofcom, U. K. (2016). Children and parents: Media use and attitudes report. London: Office of Communications London.

Okyere, C. Y. (2020). The effect of internet services on child education outcomes: evidence from poa! Internet in Kenya. Journal of Development Effectiveness, 1-15.

https://doi.org/10.1080/19439342.2020.1829001

Pigato, M. (2001). Information and communication technology, poverty, and development in sub-Saharan Africa and South Asia. World Bank. 
Plowman, L., Stevenson, O., Stephen, C., \& McPake, J. (2012). Preschool children's learning with technology at home. Computers \& Education, 59(1), 30-37.

Polizzi, G. (2020). Digital literacy and the national curriculum for England: Learning from how the experts engage with and evaluate online content. Computers \& Education, 152, 103859.

Pool, C. R. (1997). A new digital literacy: A conversation with Paul Gilster. Educational Leadership, 55(3), 6-11.

Pyżalski, J. (2012). From cyberbullying to electronic aggression: Typology of the phenomenon. Emotional and Behavioural Difficulties, 17(34), 305-317. https://doi.org/10.1080/13632752.2012.704319

Robinson, E. (2013). Parental involvement in preventing and responding to cyberbullying. Family Matters, 92, 68-76.

Rodríguez de Dios, I. (2018). Risks of interactive communication in adolescents. Digital literacy diagnosis and intervention (Doctoral dissertation, University of Salamanca).

Rouchun, D., Zongkui, Z., Shuailei, L., Qingqi, L., \& Chen, G. (2019). Family socioeconomic status and the parent-child relationship: Children's Internet use as a moderated mediator. Current Psychology, 1-10. https://doi.org/10.1007/s12144-019-00356-0 Savage, M. (2015). Digital literacy for primary teachers. Critical Publishing.

Shipton, L. (2011). Improving e-safety in primary schools: a guidance document. Centre for Education and Inclusion Research Sheffield Hallam University.

Sonck, N., \& de Haan, J. (2013). How the internet skills of European 11 -to 16-year-olds mediate between online risk and harm. Journal of Children and Media, 7(1), 79-95. https://doi.org/10.1080/17482798.2012.739783

Sonck, N., \& de Haan, J. (2014). Safety by literacy? Rethinking the role of digital skills in improving online safety. In S. van der Hof, B. van den Berg \& B. Schemer (Eds.), Minding minors wandering the Web: Regulating online child safety (pp. 89-104). Springer.

Sonck, N., Livingstone, S., Kuiper, E., \& de Haan, J. (2011). Digital literacy and safety skills. EU Kids Online, London School of Economics \& Political Science, London, UK. 
Staksrud, E., Ólafsson, K., \& Livingstone, S. (2013). Does the use of social networking sites increase children's risk of harm?. Computers in human behavior, 29(1), 40-50.

Tatnall, A. (1992). The Growth of Educational Computing in Australia. In I.F. Goodson \& J.M. Mangan (Eds.), History, Context, and Qualitative Methods in the Study of Education (pp. 207-248). University of Western Ontario.

Tatnall, A., \& Davey, B. (2004). Improving the chances of getting your IT curriculum innovation successfully adopted by the application of an ecological approach to innovation. Informing Science: International Journal of an Emerging Transdiscipline, 7, 87-103.

Taylor, A., \& Dalal, H. A. (2014). Information literacy standards and the World Wide Web: results from a student survey on evaluation of Internet information sources. Information Research: An International Electronic Journal, 19(4), n4.

Tomczyk, Ł. (2019). What Do Teachers Know About Digital Safety? Computers in the Schools, 36(3), 167-187. https://doi.org/10.1080/07380569.2019.1642728

Tran, T., Ho, M. T., Pham, T. H., Nguyen, M. H., Nguyen, K. L. P., Vuong, T. T., ... \& La, V. P. (2020). How digital natives learn and thrive in the digital age: Evidence from an emerging economy. Sustainability, 12(9), 3819. https://doi.org/10.3390/su12093819

UNESCO (2018). Global framework of reference on digital literacy skills for indicator 4.4.2: Percentage of youth/adults who have achieved at least a minimum level of proficiency in digital literacy skill (Draft Report). Paris: UNESCO.

Urbancikova, N., Manakova, N., \& Ganna, B. (2017). Socio-economic and regional factors of digital literacy related to prosperity. Quality Innovation Prosperity, 21(2), 124-141. https://doi.org/10.12776/qip.v21i2.942

Vandoninck, S., d'Haenens, L., \& Roe, K. (2013). Online risks: Coping strategies of less resilient children and teenagers across Europe. Journal of children and media, 7(1), 60-78. 
Vraga, E. K., Tully, M., Kotcher, J. E., Smithson, A. B., \& BroeckelmanPost, M. (2015). A multi-dimensional approach to measuring news media literacy. Journal of Media Literacy Education, 7(3), 41-53.

Whittle, H. C., Hamilton-Giachritsis, C. E., \& Beech, A. R. (2014). "Under his spell": Victims' perspectives of being groomed online. Social Sciences, 3(3), 404-426. https://doi.org/10.3390/socsci3030404

Zhang, H., \& Zhu, C. (2016). A study of digital media literacy of the 5th and 6th grade primary students in Beijing. The Asia-Pacific Education Researcher, 25(4), 579-592.

https://doi.org/10.1007/s40299-016-0285-2

Wilkins Ndege Muhangi is a Lecturer at the Department of Community Development of Pan Africa Christian University, Kenya Johnson Nzau Mavole is a Senior Research Fellow at St. Augustine University of Tanzania

Mumo Nzau is a Lecturer at the Institute of Diplomacy and International Studies, University of Nairobi, Kenya

Corresponding author: Wilkins Ndege Muhangi

Email: wilkndege@gmail.com 